\title{
Optimalisasi Peranan Dudi Sebagai Penguatan Ekosistem Pendidikan Di Sekolah Satu Atap
}

\section{Surtini}

SMPN 3 Tualang

surtini.haryadi@gmail.com

\section{Article History}

accepted 01/12/2020

approved 01/01/2021

published 01/03/2021

\begin{abstract}
Schools as educational institutions must continue to strive to meet the determined standards. Although many limitations should not be used as an excuse for the inability of schools to develop themselves. Schools must take advantage of existing resources and must not give up and surrender to the situation, one of which is by optimizing the Role of the industrial world business world (DUDI). In embracing the business world and the industrial world, prioritize the principle of cooperation .
\end{abstract}

Keywords: school, industry, optimization, cooperation, standard

\section{Abstrak}

Sekolah sebagai lembaga pendidikan, harus terus berupaya untuk memenuhi standar yang telah ditentukan. Walaupun banyak keterbatasan tidak boleh dijadikan alasan ketidakmampuan sekolah dalam mengembangkan dirinya. Sekolah harus memanfaatkan sumber daya yang ada dan tidak boleh menyerah dan pasrah terhadap keadaan salah satunya dengan mengoptimalkan Peranan dunia usaha dunia industri (DUDI). Dalam merangkul pihak dunia usaha dan dunia industri, utamakan prinsip kerja sama.

Kata kunci: sekolah, industri, optimalisasi, kerja sama, standar

Social, Humanities, and Education Studies (SHEs): Conference Series https://jurnal.uns.ac.id/shes

p-ISSN 2620-9284

e-ISSN 2620-9292 


\section{PENDAHULUAN}

Pembangunan SD-SMP satu Atap merupakan program pemerintah yaitu Kementerian Pendidikan dan Kebudayaan yang sudah dicanangkan sejak tahun 2005 dan merupakan program pemerintah dalam upaya mensukseskan wajib belajar 9 tahun. bertujuan menekan angka anak putus sekolah yang ada di daerah terpencil. Program satap adalah jenjang pendidikan SD-SMP dimana kegiatan belajar mengajar dilakukan dalam satu atap ( lokasi ) dengan tujuan memberi kesempatan dan mempermudah anak - anak untuk mendapatkan pendidikan yang lebih layak sampai jenjang SMP.

Sekolah Menengah Pertama Negeri 3 Satu Atap Tualang merupakan sekolah yang dibangun guna memenuhi kebutuhan akan pendidikan di daerah yang relatif jauh dari perkotaan. Sekolah ini dibangun untuk mengakomodir anak-anak yang berasal dari SDN 18 Maredan dimana mayoritas orang tuanya bekerja dibidang perkebunan sawit.

Sekolah ini terletak $\pm 35 \mathrm{Km}$ dari ibu kota kecamatan tepatnya didesa Maredan sekolah ini mempunyai tantangan tersendiri, diantaranya jarak yang cukup jauh sehingga cenderung terisolir belum adanya aliran listrik dan akses jalan pada awalnya jalan tanah merah namun pada saat ini sudah diaspal, sehingga saat ini akses untuk mencapai sekolah Satu Atap ini mudah. Namun dalam hal pemenuhan kebutuhan akan sarana dan prasarana sekolah masih jauh dari perhatian pemerintah. Pada saat awal berdirinya sekolah, belum banyak siswa yang bersekolah di sekolah satu Atap ini. Alasan mutu atau sarana prasarana sekolah yang boleh dibilang apa adanya menimbulkan rasa pesimis orang tua akan sekolah ini. Mereka kuatir anaknya tidak dapat belajar dengan baik dan cenderung mengirim anaknya bersekolah di kota kecamatan ataupun kota Pekanbaru walaupun dengan resiko jauh dari rumah ataupun hidup berpisah.

Begitu juga dengan guru yang mengajar. Banyak guru yang tidak berminat untuk mengajar di sekolah Satu Atap ini. Selain jauh dari kota atau pemukiman penduduk, sarana dan prasarana sekolah Satu Atap inipun masih jauh dari standar pelayanan minimum. Wajar saja jika para guru berpikir panjang untuk mengajar di sekolah Satu Atap ini. Karena untuk mengajar mereka membutuhkan biaya extra untuk transportasi. Hanya guru yang dengan dedikasi tinggilah yang bersedia mengajar di sekolah Satu Atap ini.

Keadaan yang demikian memotivasi kepala sekolah untuk memberdayakan potensi yang ada guna menyelenggarakan sekolah dengan 8 standar nasional Pendidikan yang tidak kalah dengan sekolah yang ada di kota kecamatan. Sehingga sekolah Satu Atap ini dapat memberikan kepercayaan masyarakat sekitar untuk menitipkan anaknya bersekolah di SMPN 3 Satu Atap Tualang.

SMPN 3 Satu Atap Tualang dihadapkan pada persoalan yang kompleks, kondisi sarana dan prasarana sekolah yang belum memadai dan karakteristik dari siswanya yang sebagian besar berlatar belakang keluarga pekerja/buruh pabrik/perkebunan membuat banyak orang pesimis dengan potensi sekolah ini. Pemerintah memberikan dana BOS, namun dengan murid yang relatif sedikit mulai dengan awal berdirinya sekolah hanya 7 siswa tahun 2011/2012 berdampak penerimaan dana BOS yang relatif sangat sedikit juga sehingga sekolah akan sulit untuk berkembang, dan untuk berkembang akan membutuhkan waktu yang lama. Dengan demikian, diperlukan langkah-langkah yang dapat mengoptimalkan peranan DUDI (dunia usaha dan dunia industri) untuk menunjang kegiatan pendidikan di sekolah satu atap ini, mengingat di daerah ini terdapat beberapa pabrik / perkebunan walaupun letaknya relatif berjauhan.

Keterbatasan infrastruktur sarana prasarana sekolah untuk mengakomodasi pengalaman belajar dapat memperlemah proses belajar-mengajar. Hal ini tercermin 
dari kecilnya jumlah curahan waktu siswa untuk aktif belajar. Kecenderungan di atas diperkirakan akan terus berlanjut apabila infrastruktur masih belum dapat ditingkatkan. Hal ini sangat besar pengaruhnya terhadap menurunnya baik motivasi siswa ataupun orang tua dalam proses pembelajaran.

Salah satu kekurangan sarana dan prasarana yang paling dirasakan adalah ketiadaan air bersih untuk sarana sanitasi sekolah dan tidak adanya listrik. Letak sekolah di dataran yang tinggi (di tengah kebun sawit) menyebabkan air tidak dapat diperoleh hanya dengan membuat sumur cincin atau sumur bor biasa. Dibutuhkan sumur bor dengan kedalaman 100 meter dan ini membutuhkan biaya yang tidak sedikit. Sekolah tidak mampu untuk mengalokasikan biaya operasionalnya untuk membuat sumur bor dengan kedalaman $100 \mathrm{~m}$. Sehingga untuk mengatasi hal ini untuk sementara sekolah membuat penampungan air tadah hujan Keadaan ini tentunya mengganggu proses belajar mengajar. Hal inilah yang perlu dicari solusinya oleh pihak sekolah untuk menciptakan sekolah yang nyaman. Jika masalah yang utama saja tidak dapat diselesaikan bagaimana dengan masalah lainnya. Motivasi ini juga yang mendorong Kepala sekolah dan warga sekolah untuk berkreativitas mengatasi masalah. Adapun rumusan masalah pada kajian ini adalah bagaimana upaya SMPN 3 Satu Atap Tualang mengoptimalkan peranan dunia usaha dan dunia industri untuk berperan dalam membangun pendidikan di daerah, untuk bersama sama untuk menguatkan ekosistem pendidikan.

\section{HASIL DAN PEMBAHASAN}

Standar Nasional Pendidikan Menurut BSNP: yang terdiri dari Standar Kompetensi Lulusan, Standar Isi, Standar Proses, Standar Pendidikan dan Tenaga Kependidikan, Standar Sarana dan Prasarana, Standar Pengelolaan, Standar Pembiayaan Pendidikan, Standar Penilaian Pendidikan. Dari 8 standar tersebut, Standar Sarana dan Prasarana adalah standar yang sulit dicapai oleh sekolah satu atap atau sekolah yang letaknya terpencil. Setiap satuan pendidikan wajib memiliki sarana yang meliputi perabot, peralatan pendidikan, media pendidikan, buku dan sumber belajar lainnya, bahan habis pakai, serta perlengkapan lain yang diperlukan untuk menunjang proses pembelajaran yang teratur dan berkelanjutan.

Setiap satuan pendidikan wajib memiliki prasarana yang meliputi lahan, ruang kelas, ruang pimpinan satuan pendidikan, ruang pendidik, ruang tata usaha, ruang perpustakaan, ruang laboratorium, ruang bengkel kerja, ruang unit produksi, ruang kantin, instalasi daya dan jasa, tempat berolahraga, tempat beribadah, tempat bermain, tempat berkreasi, dan ruang/tempat lain yang diperlukan untuk menunjang proses pembelajaran yang teratur dan berkelanjutan.

Strategi Kementerian Pendidikan dan Kebudayaan pada periode 2014-2019 tidak semata-mata pada terbentuknya insan pendidikan yang cerdas, tapi juga ekosistem pendidikan yang cerdas dan berkarakter dengan dilandasi semangat gotong royong. Atas strategi itulah, dibentuk Direktorat Pembinaan Pendidikan Keluarga, yang salah satu aksinya adalah penguatan ekosistem pendidikan. penguatan para pelaku pendidikan, seperti kepala sekolah, guru, komite sekolah, orang tua, dan juga ada pegiat pendidikan yang aktif dalam community development.

\section{Dunia Usaha dan Dunia Industri (DUDI)}

Tanggung jawab Sosial Perusahaan atau Corporate Social Responsibility (CSR) adalah suatu konsep bahwa organisasi, khususnya perusahaan memiliki berbagai bentuk tanggung jawab terhadap seluruh pemangku kepentingannya, yang di antaranya adalah konsumen, karyawan, pemegang saham, komunitas dan lingkungan dalam segala aspek operasional perusahaan yang mencakup aspek ekonomi, sosial, 
dan lingkungan. CSR merupakan suatu komitmen berkelanjutan oleh dunia usaha untuk bertindak etis dan memberikan kontribusi kepada pengembangan ekonomi dari komunitas setempat ataupun masyarakat luas, bersamaan dengan peningkatan taraf hidup pekerjanya beserta seluruh keluarganya.

Penguatan sinergi antara keluarga, sekolah, dan masyarakat dan DUDI, diharapkan dapat ikut mendorong dan meningkatkan mutu layanan pendidikan yang ada di daerah. Perlu kita ketahui bahwa syarat utama yang diperlukan untuk membangun kepercayaan dari pihak DUDI, tidak lain adalah adanya transparansi, demokratisasi, dan akuntabilitas yang dilakukan oleh semua komponen pendidikan.

\section{Ekosistem Pendidikan}

Secara teori, ekosistem adalah suatu proses yang terbentuk karena adanya hubungan timbal balik antara makhluk hidup dengan lingkungannya. Sedangkan yang dimaksud dengan ekosistem pendidikan adalah suatu proses pelaksanaan pendidikan yang melibatkan berbagai komponen yang saling mempengaruhi terhadap hasil pendidikan tersebut. Jadi yang termasuk dalam ekosistem suatu pendidikan secara umum yaitu sekolah dengan peserta didik, guru orang tua (wali murid), masyarakat, pemerintah dan swasta (dalam hal ini dunia usaha dan dunia industri).

Suatu ekosistem tersebut akan terganggu jika salah satu komponen pendukung tidak memberikan peranannya. Untuk itu perlu dijaga sistem komunikasi yang baik antara komponen dari ekosistem pendidikan sekolah.

Dengan mengacu pada pemenuhan 8 standar nasional pendidikan sekolah yang merupakan sebuah prasyarat bagi sekolah untuk lebih mampu mencapai tujuan yang diharapkan, SMPN 3 Satu Atap Tualang berupaya memanfaatkan sumber daya yang ada termasuk dukungan pemerintah daerah dan dunia usaha dan dunia industri (dudi). Sekolah berupaya melengkapi fasilitas penunjang pendidikan dan pemanfaatan tehnologi.

Selain pemenuhan fasilitas penunjang, sekolah juga berupaya membangun komunikasi dengan pihak orang tua yang umumnya berprofesi sebagai buruh/pekerja pabrik/perkebunan dan manajemen tempat orang tua siswa bekerja. Dengan adanya komunikasi yang baik diharapkan peran orang tua dapat mendorong anaknya untuk bersekolah. Dukungan ini perlu mengingat jarak tempuh dari rumah ke sekolah cukup jauh (kurang lebih 1 jam)

Kerja sama yang baik antara sekolah, orang tua, pemerintah daerah dan perusahaan (dunia usaha dan dunia industri) tempat orang tua bekerja inilah yang dibangun oleh SMPN 3 Satu Atap sehingga terciptanya optimalisasi peranan DUDI sebagai penguatan ekosistem pendidikan di SMPN 3 Satu Atap.

Adapun hasil yang diperoleh

1. Bantuan sumur bor untuk sanitasi sekolah.

CSR PT. Palu Indah yang bergerak dibidang penyediaan aspal dan kerikil, membantu dalam pembuatan sumur bor. Sedangkan untuk tempat penampungan air di bantu oleh PT. Bumi Siak Pusako yang bergerak dibidang minyak bumi.

2. Bantuan Pengadaan Listrik / Generator Set

Di sekolah SMPN3 Satu Atap belum tersedia jaringan listrik yang di supply oleh negara (PLN) sehingga untuk kebutuhan listrik sendiri memerlukan suatu pembangkit listrik untuk konsumsi sendiri. Yang dibantu CSR PT. Bumi Siak Pusako

3. Bantuan Tranportasi.

Bantuan fasilitas transportasi berupa bus untuk mobilitas rutin siswa dari camp atau perumahan karyawan perusahaan,dan Untuk aktivitas diluar jam sekolah 
dikarenakan tidak adanya transportasi umum, kegiatan pendidikan di luar jam sekolah yang dibantu dari CSR PT Maredan Surya Planation (PT.MSSP)

4. Bantuan Sarana Penghijauan.

Bantuan pupuk dari limbah tangkos kelapa sawit. Limbah tangkos kelapa sawit ini sangat baik untuk dijadikan pupuk organik, untuk menunjang program penghijauan sekolah. Selain itu melalui program CSR PT. MSSP

5. Bantuan Mobiler Kantor Kepala Sekolah

Setelah berdiri sejak tahun 2011 akhirnya SMPN 3 Satu Atap Tualang Kabupaten Siak Provinsi RIAU, akhir 2016 barulah memiliki ruang kantor untuk guru, kepala sekolah dan Tata Usaha yang dibangun dari dana Pemerintah Daerah dan untuk mobiler ruang kepala sekolah mendapat bantuan dari CSR PT Indah Kiat Pulp and Paper

6. Bantuan Mushola

Berdirinya mushola dengan swadaya warga sekolah dan masyarakat pada tahun 2018 dimana dengan berdirinya mushola ini sangat membantu sekolah dalam melaksanakan pembelajaran MDTW ( Madrasah Diniyah Takmiliyah Whustho) dimana siswa belajar Agama sampai pada jam 16.00 dan melaksakan sholat zhuhur dan Ashar berjamaah.

Dengan demikian, meningkatnya peminat siswa untuk belajar di sekolah ini tidak terlepas dari peranan ekosistem pendidikan di sekolah. Dimana semua komponen berkontribusi dalam memajukan pendidikan di daerahnya.

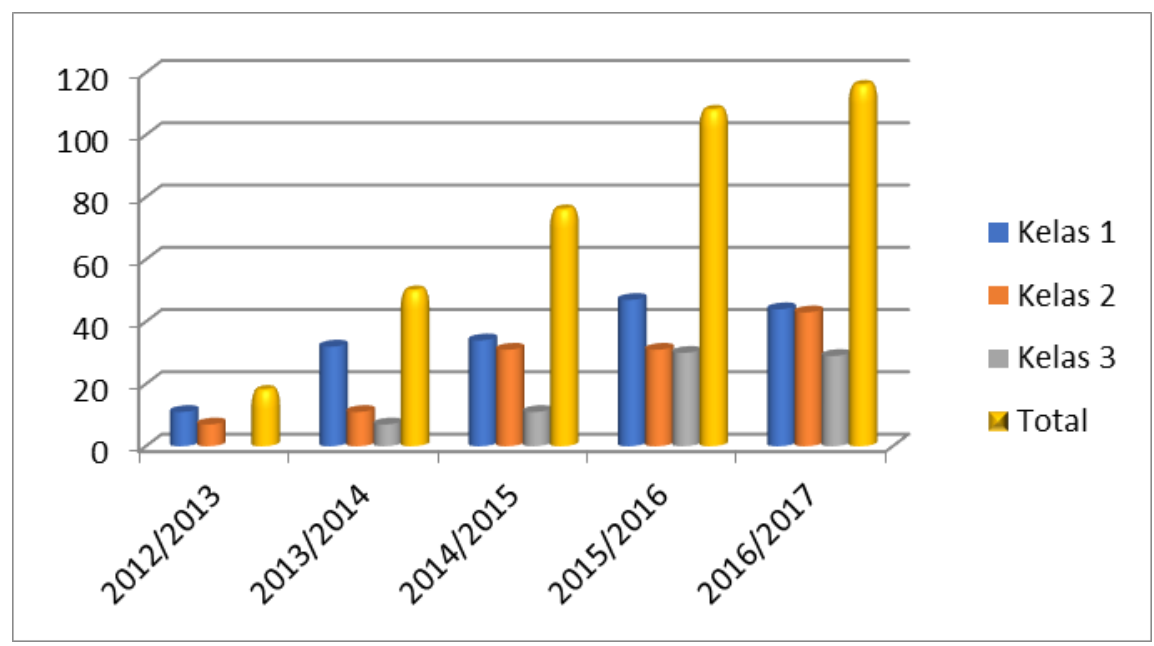

Gambar 1. Grafik Perkembangan Jumlah Siswa

\section{SIMPULAN}

Sekolah sebagai lembaga pendidikan, harus terus berupaya untuk memenuhi standar yang telah ditentukan. Walaupun banyak keterbatasan tidak boleh dijadikan alasan ketidakmampuan sekolah dalam mengembangkan dirinya. Sekolah harus jeli memanfaatkan sumber daya yang ada dan tidak boleh menyerah dan pasrah terhadap keadaan salah satunya dengan mengoptimalkan Peranan DUDI. Dalam merangkul pihak dunia usaha dan dunia industri, utamakan prinsip kerja sama. Dunia usaha dan dunia industri bukanlah menyumbang sekolah melainkan mereka berinvestasi jangka panjang. Jika sekolah maju dan berkembang maka sekolah tersebut dapat menghasilkan sumber daya manusia yang handal yang dapat bekerjasama dengan dunia usaha dan dunia industri untuk melakukan regenerasi pekerja. Dengan kata lain 
dunia usaha dan dunia industri mengeluarkan investasi jangka panjang untuk menciptakan regenerasi sumber daya manusia yang handal.

Sekolah dapat mengadakan pertemuan minimal satu tahun sekali dengan pihak DUDI melaporkan jalannya proses pendidikan dan hasil yang dicapai dan juga melaporkan penggunaan dana secara transparan, untuk menigkatkan kepercayaan kepada sekolah.

\section{DAFTAR PUSTAKA}

Permendikbud Nomor 22 tahun 2015 tentang Rencana Strategis Kemdikbud Tahun 2015-2019

Permendiknas Nomor 24 tahun 2007 tentang standar sarana dan prasarana Sekolah/Madrasah sekolah umum

Permendiknas Nomor 19 tahun 2007 tentang Standar Pengelolaan Pendidikan oleh satuan pendidikan Dasar dan Menengah.

https://id.wikipedia.org/wiki/Tanggung_jawab_sosial_perusahaan

https://id.wikipedia.org/w/index.php?search=ekosistem+sekolah\&title=Istimewa:Pencari an\&go=Lanjut\&searchToken=aljk5s5dtr2yhnqc0ordzpi5b 